\title{
Universality of Arthur Miller's Death of a Salesman
}

\section{Dr.K. Ramesh ${ }^{a}$, Dr.G. Christopher ${ }^{b}$, Dr.J. Karthikeyanc}

\author{
${ }^{a}$ Assistant Professor, Department of English, Sri Paramakalyani College - Tenkasi, India. \\ E-mail: krami75@gmail.com \\ ${ }^{\mathrm{b}}$ Assistant Professor Senior, Department of English, SSL, VIT - Vellore, India. \\ E-mail: christopher.g@vit.ac.in \\ ${ }^{\mathrm{c}}$ Associate Professor, Department of English, Vellore Instutute of Technology,Vellore, India. \\ E-mail: jkarthikeyan@vit.ac.in
}

Article History: Received: 11 January 2021; Accepted: 27 February 2021; Published online: 5 April 2021

\begin{abstract}
This paper aims at analyzing Arthur Miller's Death of a Salesman with a view to bring out its contemporary relevance. During its first performanace in 1949 the play shocked the American audience by its portrayal of the tragedy of the protagonist Willy Loman. The American audience were able to identify themselves with the protagonist and soon the tragedy of Willy Loman is empathised by the audience worldwide transcending spatio-temporal barriers. As put by June Schlueter, "He (Willy Loman) was a character who ...encapsulated the spirit of the ordinary man whose work ethic, pride and selfdeceptions did not admit defeat" (509). Willy commits suicide at the end of the play because of his inability to accept defeat. In fact, "Willy was the man everyone in the audience feared he would become, the man who unwittingly schooled us as a society on the need to accommodate our failures “ (509). Death of a Salesman will resonate with today's audience because of its universal theme of an individual's inability to realize his/her own dreams.
\end{abstract}

Keywords: Mediation Effect Firm Performance, Reen Innovation, Firm Value Industry.

\section{Introduction}

Change is inevitable in life. The changes occur in the broad spectrum of social, political and economic fields have the potential to alter an individual's perception of life radically. Literature reflects the impact of such changes that shape the sensibilities of people and their works, thus, can be viewed as the writers' comment on the existing socio-political matrix. A work of art cannot be produced in vacuum and to understand it the reader has to take into account the historical context at the time of the production of the text. Books as such are mere cadavers and it is the readers who breathe life into it by analyzing it. In this context, Arthur Miller's play Death of a Salesman is significant in understanding the social and economic factors that shaped the consciousness of the American society at large during the mid-half of the twentieth century. He chose to juxtapose the disorderliness of the present social and economic scenario with the peacefulness of the idyllic past through Willy Loman, the protagonist of the play. In doing so, he actually depicts how the American Dream shaped the sensibilities of the American families and eventually how the misconceived notion of the dream failed to bring peace and happiness into the households of the country. However, the struggle of Willy Loman has transcended Spatio-temporal boundaries and the play continues to inspire audiences from various countries even today. This article attempts to analyze the play to highlight how Loman's tragedy is universal and is more relevant in the market-driven twentyfirst century.

\subsection{Willy Loman's Predicament}

Willy Loman, a salesman, rode on a wave of success in the early 1920s till the Wall Street Crash of 1929 that announced the beginning of the Great Depression. He found it difficult to sell things in the 1930s when people could not afford to spend money on things other than necessities. But the revival of the economy in the 1940s renewed his hope that he might become a great salesman like Dave Singleman. However, the U.S. became a "young man's world" and "Willy, in his sixties, is swiftly becoming outmoded, and sales style also being out of date" (Abbotson, Critical Companion, 137). Set in 1948, Death of a Salesman depicts the impact of Capitalism and the rapid developments in science and technology on middle-class families. Susan Abbotson observes that the play portrays persons such as Lomans as "social failures" (Masterpieces 69) because of their inability to make money and live comfortably. But can this failure be attributed to the skimpiness of the Lomans or the effect of the "society's unrealistic standards of success?" (69). The cause of the failure of an individual is sometimes reflective of the societal values and in this case, Loman's tragedy is the result of society's expectation from an individual and his own failure to understand the reality. Jacobson views, "Society responds to him with an indifference that can only seem cruel in juxtaposition to the hopes he carries with him even to the point of death." (248) Miller has successfully created dramatic tension in this play by portraying society's indifferent respond to Willy and his false hopes Loman is portrayed as a muddle-headed person who often contradicts himself. In fact, 
he represents the unsuccessful men of his times who were considered misfits in the fast-changing, technologydriven American society. At the beginning of the play, he returns from an unsuccessful business trip without completing it because he cannot concentrate on driving his car. Willy's inability to control his car, a symbol of material success and social status, suggests his loosening grip on the forces of life that makes a successful man.

Perhaps, Willy's shattered belief that success in life is always attributed to charm, style and popularity has paved way for his tragic fall. Sterling considers that notion of being successful by being well-liked was popular in that era and "perhaps attributed to the publication of Dale Carnegie's bestseller How to Win Friends and Influence People (1936)" (3). In fact, the play was modeled on the experiences of Miller's acquaintance whose elaborate plans about the promising future of his sons became a failure. More importantly, as Bigsby observes, Death of Salesman was about "a believer in the American dream who struggles with the knowledge of his failure" (100).

\subsection{Willy Loman's Fatherhood}

The concept of the lost father is quite explicitly portrayed in Miller's plays such as All My Sons, The Crucible, The Misfits and Death of a Salesman. Though Death of a Salesman does not bear any resemblance to the personal life of Miller, an incident that happened in his life perhaps would have triggered the artistic genius of the playwright to portray the pains of a failed man. As Bigsby puts it, Miller's father, Isadore Miller, once had to "borrow money for the subway from the son" (100) because his business had collapsed. Isadore Miller, a Jewish immigrant from Poland trying to get success in America, was able to achieve it only to lose it during the stock market crash in 1929. So, when Arthur Miller revealed his plans about his higher studies, Isadore considered it a betrayal and instead wanted his son to be a successful businessman.

Perhaps, the success of the son would justify his father's decision to move to America. In this context, the father borrowing money from his son is an indication of a "major shift in power relationship" (Bigsby 100). Such a change in the domestic environment and value system is articulated in Death of a Salesman which also highlights the inability and frustration of a father in achieving success. Also, the feeling that the world is raidly changing while making the survival of social misfits like Willy Loman difficult escalates the tragic effect of the play.

Willy Loman, despite being a braggart and adulterer, is a struggling father who tried to make his sons achieve what he himself could not achieve. It seems that his whole life has been a sellout with his strained relationship with his son Biff. Sussan C. W. Abbotson observes that he is not a bad man as "he is loved by all who are close to him. It is their love that allows us to see his better side and sympathize with him" (Masterpieces of the 20th century, 64). He, in fact, showered his love on the family and eventually sacrificed his own life for the sake of the family. It proves that he is more responsible than his father and brother Ben who evaded their familial responsibility by running away from it while Willy Loman has stayed with the family and constantly tried to support it.

However, his integrity to his family cannot be accepted without being questioned. His extramarital affair with a lady brings out his weakness and resulted in his strained relationship with his son Biff. The subtle portrayal of Willy's subjective life, according to Neil Carson, has made the critics approach the play as a "psychological play with Freudian colouring" (49). They consider that the failure of Willy is actually caused by his strained relationship with Biff. When Biff fails to get 'success' as expected by his father, Willy got frustrated with life itself. In this sense, he represents the pangs of a father for not witnessing the success of his son and the audience and readers can sense its relevance. However, not all critics consider Willy as a symbol of fatherhood. Loman is not, according to Irving Jacobson, a "modern Everyman but an anomaly, a bourgeois romantic and an odd synthesis of Joe and Chris Keller, or...Faust" (247). Jacobson considers Willy's inability to deal with reality as the cause of his failure. It is interesting to note that Neil Carson considers that in Death of a Salesman Miller "has projected a character quite unlike himself" (44) and the play is written "from the point of the view of the father rather than the alienated son" (44) and is considered the dramatist's "most successful attempt in creating individual characters with universal significance" (44)

\subsection{Peaceful Past Vs Chaotic Present}

Willy Loman's failure as a salesman at an old age is quite different from what he experienced at his young age. Life in the past was a comparatively less chaotic and human relationship was not altogether decided by material success. For example, the readers understand Willy's success in the past from his interaction with Howard though it is questioned by the latter, " ... in 1928 I had a big year. I averaged a hundred and seventy 
dollars a week in commissions." (Death of a Salesman, 62). However, the present scenarios demanded that Willy could no longer boast about his success in the past. He even pleaded to Howard that all he needed was just forty dollars. But when Howard was not interested in listening to him, Willy expressed his anger, "I put thirty-four years into this firm... You can't eat the orange and throw the peel away - a man is not a piece of fruit" (Death of a Salesman, 61). The anguish of Willy Loman is contrasted with the success of his brother Ben. Ben left home when he was young and never returned. His appearances on stage are metaphorical and are used by the author to contrast the entropic present with the negentropic past.

Ben's arrival on stage actually reveals to the readers what happens inside the mind of Willy Loman. Rejecting the word 'flashback' to point out Willy's dwelling on the past while experiencing the present, Peter Spalding prefers to call it 'time switch' (8). It is quite common that some memories are remarkably vivid that we consider that we are actually experiencing them. Most of Willy's time switches indicate that he actually loves his past more than the present because the past appears to have some order, at least according to Willy. But he has the quality of retaining the mood when he returns from the past to the present. In fact, the juxtaposition of the past and the present on stage suggests the juxtaposition of the value systems prevalent in America before and after the Wall-Mart crash. Annette J. Saddik points out that in Death of a Salesman, "the risk of a capitalist system that offers the possibility of becoming a millionaire with minimal effort, an opportunity theoretically open to all Americans, are juxtaposed with more conservative American values that offer security, embracing ard work and the establishment of a solid, but perhaps less glamorous, place in society" (59).

\subsection{Contemporary Relevance of Death of a Salesman}

Viewed generally as a tragedy caused by the failure of the American Dream, Death of a Salesman appears to be a play that suits the twentieth century in transition. Willy's words to Howard suggests that the tussle between the past and the present is always felt. "There was respect, and comradeship, and gratitude in it. Today it is all cut and dried, and there is no chance for friendship to bear - or personality" (Death of a Salesman 61). Actually, it goes beyond the Spatio-temporal limitations of the milieu in which it was written by its projection of an individual's ineptness in acclimatising himself to the changing environment. In fact, it deals with many societal problems such as unemployment, strained family relationships, chasing unrealized dreams, inability to acclimatise oneself to the changing environment. Though our sympathies lie with Willy Loman, the truth that he upheld false values right from the beginning of his career cannot be denied. In fact, his preference for societal recognition as the yardstick for measuring the success of an individual has lost its ground in a society under transformation. The new millennium began with great euphoria highlighting the ambitious attempt of mankind to make this world a better place to live in aided by the rapid strides of technology. However, the chasm between the different sections of the society is felt now during the time of crisis.

When we compare Willy and his neighbour Charlie, we understand that Charlie's pragmatism which is pitted against Willy's romanticism is instrumental in preventing him from suffering. In fact, Willy and Charlie are the outcome of Miller's creative genius and are the symbolic representations of universal human nature. Miller views theatre, not as a mode of disconnected entertainment but he believes that it echoes the spirit of the people. Julius Novick quotes Miller to highlight the symbiotic relationship between the theatre and the audience: "It (theatre) is where a collective mass of people through the genius of some author, is able to projects its terrors and its hopes and symbolise them" (131). Such a human dilemma is universal especially for those who could not adapt themselves to face the new challenges caused by the changing global scenario. Thus the predicament of Willy Loman is universalised.

In his interview with Arthur Miller in 2000 Enoch Brater posed a sensible question wheter Miller would make any changes if he were to write Death of a Salesman or All My Sons or The Crucible. Miller reiterated that he would not make any changes as he considered that it was a mistaken idea to consider a playwright of one period is outdated in the next period. According to Miller, "the modernity of a play is based on its inner feelings, its original grasp of ideas" (Brater 250). Death of a Salesman deals with the problem of an individual in a society which is under rapid transformation and thus yields itself to different interpretations in different eras.

\section{Conclusion}

Death of a Salesman is about an ordinary man with many dreams and delusions. While chasing his dreams Willy develops a false perception that personal attractiveness will eventually lead to professional success. Willy's desparate attempts to find success at least though his sons actually signals the disintegration of a man with his own inability to acclimitise himself with the changing society. At one stage Willy lost his control during his struggle to hold on to his dream. He started living in the past which offered him the much needed comfort. 
While the future looked uncertain, Willy was secure in his dream and committed suicide hoping that at least the insurance money would help his son Biff to be magnificent. The pang of an unsettling and unsuccessful person is well crafted by Miller and people of all eras sympathise Willy. More than sympathising what is required is the readers' understanding that the only way to prevent such tragedy is to adapt oneself to the chaning environment and equip oneself to face reality.

\section{References}

1. Abbotson, S.C. (2007). Critical Companion to Arthur Miller:a literary reference to his life and work. Infobase Publishing.

2. Abbotson, S.C. (2005). Masterpieces of 20th-century American drama. Greenwood Publishing Group.

3. Bigsby, C., \& Bigsby, C.W. (2005). Arthur Miller: a critical study. Cambridge University Press.

4. Brater, E. (2005). A Conversation with Arthur Miller. Arthur Miller's America: Theater \& Culture in a Time of Change. Ed. Enoch Brater. Michigan, The University of Michigan Press, 244-255.

5. Carson, N. (1982). Arthur Miller. London: Mcmillan.

6. Jacobson, I. (1975). Family dreams in Death of a Salesman. American literature, 47(2), 247-258.

7. Miller, A. (1976). Death of Salesman (Certain Private Conversations in Two Acts and a Requiem). New York: Penguin Books.

8. Novick, J. (2007). Death of a Salesman: Deracination and Its Disicontents. Bloom's Modern Critical Views: Arthur Miller. Ed. Harold Bloom. New York: Infobase Publishing, 131-141.

9. Saddik, J.A. (2007). Contemporary American Drama (Edingburgh Critical Guides). Edinburgh: Edinburgh University Press.

10. Schlueter, J. (2005). American Drama of the 1990s On and Off-Broadway. A Companion to TwentiethCentury American Drama, 504-518.

11. Spalding, P. (1987). Death of a Salesman by Arthur Miller. Macmillan Education.

12. Sterling, E., \& Sterling, EJ. (Eds.). (2008). Arthur Miller's Death of a Salesman Rodopi, 3. 